\title{
アオエリヤケイ（雄）と岐阜地鶏（雌）から 得られた交雑種 $\left(\mathrm{F}_{1}\right)$ の染色体
}

\author{
岡本 新・中山統雄・前田芳實・橋口 勉 \\ 鹿児島大学農学部，鹿児島市 890
}

(1991. 1. 25 受付)

\begin{abstract}
要 約『オエリヤケイ（Gallus varius）と吱皁地鵎（Gallus domesticus）の自然交配によっ て得られた $F_{1}$ (雌) の染色体は，相対的長さおよび捥比など形態的特徴加らNos. 1，2，3，4 染色体 の由来について推定することが可能であった，一方，Nos５，6，7，8および9については，由来を確 認することが困難であった，性染色体については，F、婔であり，作出に供試した丁オエリヤケイが 雄, 岥阜地鶏が雌であることから，Z染色体がアオエリヤケイ，W 染色体が岐卓地慆内来でするこ上

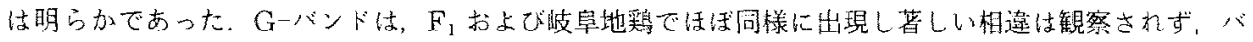
ンドから由来を追求することはできなかった。アオエリヤケイおよび岐阜地鶏の大型染色体間では, G-バンドのパターンに招いて非常に高い相同性が存在した。
\end{abstract}

日畜会竍，62 $(8) ： 735-741 ， 1991$

野鵎相互間あるいは野鷄とニワトり間における交雑種 に関しては，いくつかの報告がある。KIMBALL ${ }^{3)}$ セキショクヤケイと八イイロヤケイとの交雑に上り交雑 種 $\left(\mathrm{F}_{1}\right)$ 老得ることができ，また正逆交嚾古可能であ るとしている. DERANYAGALA ${ }^{2)}$ は，セイロンヤケイよ バンタム種およびセキショクヤケイとセイロンヤケイの 交雑に成功している。西田ら は（七キショクかケイ上 アオエリヤケイが重複して生息しているジャワ，バリお よびロンボクでは，セキショクヤケイとニりトリ閐にお いては交雑が行なわ犯が，ア木エリヤケイとニワトり の問では自然交雑は行なわれないと報告している。ニワ トリの祖先種について考祭する場合，交雑に上り子孫の 作出が可能であるか，また子孫に繁殖力があるかという 点は重要である４種野鵎の染色体については，OKAMOTO et $a l .{ }^{6)}$ が，その数および核型を明らかにし，4 種間に著しい相違は認められないと報告しているが，二 ワトリとの詳細な此較は行なわれていない。

著者らは，こ机まで路䳝さニワトリとの交雑種の作出 を試みてきた。艺の結果，今可ア才エリヤケイ〈Gallus varius）を父鵎とし，日在来舀の１品種である岐早 地瓶（Gallus domesticus）を母鴊上するバドック内 の自然交配により $F_{1}$ (雌) 孛得るこよが゙きた。この $\mathrm{F}_{1}$ の分裂中期細胞について考えてみると、アオエリヤ
ケイ由来の染色体と岥㔬地鵎由来の染色体加问数で，し 加香相问染色体上いう状態で存在しているのが観察され る上思功る、るれは、アオエリヤケイとニワトりの関 連を細胞遺伝学的観点加ら追求する上で非常に與味深い ことである，1 つの細胞内すなわち同一条件下で，アオ エリヤケイ由来打よびニワトリ由来の染色体の比较検討 が可能にな机ば，染色体㺼满識として二ワトリとアオエ リヤケイの関速がより朋確になると考えられる。

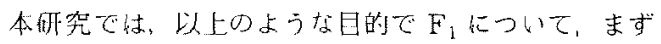
核型の同定を行ない，己らにG-分染法を併用して老の 染色体について検討した。

\section{材料および方法}

染色体観察には，アオエリヤケイ(雄)，貱阜地鷅 (雌，50週齢）抢よびそれらの交雑によって得られた $F_{1}$ (雌，20週㱓) をそれぞれ1個体ずつ供試した，尺湖皮 静脈よりへパリン 100 耑位を含ませた注射简で採血老行

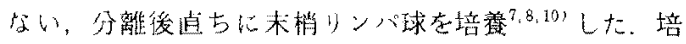
羕終了後は常法に徒い，低張処理，力ルアア固定老行な っだ，標本は，蒸気乾燥法に上って作製し，5\%ギムザ 溶淮（pH 6.8）で10 分間染色５分間水洗とした，G-

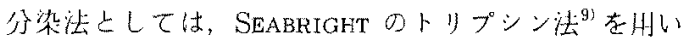
t. 
岡本・ 中山・前田・橋口

$F_{1}$ の染色体の分析は、まずギムザ染色を施した標本 の中で重なりが少なく分散がない分裂中期像を選び，各 細胞について大型の 20 本の染色体の計測を行ない，大 きさの順に番号をつけ，相対的長さ (Relative length： RL) を求めた，その後，腕比 (Arm ratio：AR）お よび着系点指数 (Centromere index：CI) を算出し 核型の同定後, 両親のものと比較した。一般に RL は, X 染色体を含む半数染色体（n）の長さの総和に対する 各染色体の長さの比であるが ${ }^{1,4)}$ ，本研究においては， 性染色体 ZW 在含む 20 本の染色体の長さの総和に対す る各々の染色体の比を百分率で表した，G一分染法によ る標本については，F，のバンドの数招よび出現状態を 観察し，母親である岐皁地鵎のそれと比較して，F 染色体の山来について推测した。拉父親である了オエ リヤケイについては，実験期間中に死亡したために G分染法による検討はできなかった。

\section{結果}

我1に $\mathrm{F}_{1}$ の染色体の $\mathrm{RL}, \mathrm{AR}$ おょび $\mathrm{CI}$ を示した。
計測可能な染色体数は，分裂中期細胞の状態によって異 なった，しかしながら，調查した 50 個すべての細胞に おいて，大型染色体群 20 本（10 対）の染色体の長さを 求めることが叮能であった，F $F_{1}$ の分裂中期像（図 1) は，10対（20本）の大型染色体群とその他の大部分を 占める微小染色体群より構成されていた，10対の大型 の染色休群は，大きさに従ってぺアリングを行い 9 対の 常染色体扰よび ZW の性染色体に分類した，RLは， 常染色体 9 対についてみる之相同染色体間にはほ上んど 差は認められなかった。 Nos. 1，2，4，8，Z および W については，AR およびCI の算出が可能であった。 ま た，No. 3 には，AR が求められる染色体之求められ ない染色体が存在した，すなわち動原体を境に腕がある もの上ないあのに分けられた。なお，アオエリヤケイの No. 3 は AR の算出できる染色体であり, 岥阜地鶏の それは AR が算出できない染色体であった．その他の Nos. 5，6，7 よむ゙ 9 は，AR の確認できない端部動

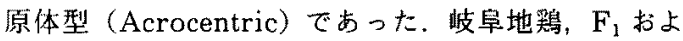
びアオエリヤケイの Nos. 1，2，3，4，8 抢よび Z, W

Table 1. Relative length (RL), arm ratio (AR) and centromeric index (CI) of $\mathrm{F}_{1}{ }^{\prime \prime}$.

\begin{tabular}{cccc}
\hline \hline \multirow{2}{*}{$\begin{array}{c}\text { Chromosome } \\
\text { No. }\end{array}$} & \multicolumn{3}{c}{$\mathrm{F}_{1}\left(\operatorname{mean} \pm \mathrm{S} . \mathrm{D} .{ }^{2)}\right)$} \\
\cline { 2 - 4 } 1 & $13.06 \pm 1.40$ & $\mathrm{AR}$ & $\mathrm{CI}(\%)$ \\
\hline \multirow{2}{*}{2} & $12.93 \pm 1.26$ & $1.52 \pm 0.16$ & $38.98 \pm 2.42$ \\
& $9.43 \pm 0.78$ & $1.83 \pm 0.21$ & $35.26 \pm 2.47$ \\
3 & $9.39 \pm 0.92$ & $1.89 \pm 0.19$ & $34.77 \pm 2.27$ \\
& $7.62 \pm 0.61$ & $1.64 \pm 0.46$ & $34.88 \pm 9.71$ \\
4 & $6.38 \pm 0.54$ & $4.94 \pm 1.20$ & $17.57 \pm 3.92$ \\
& $5.46 \pm 0.49$ & $3.32 \pm 1.90$ & - \\
5 & $5.44 \pm 0.40$ & $3.75 \pm 0.97$ & $23.94 \pm 4.18$ \\
& $3.66 \pm 0.41$ & - & $21.78 \pm 3.74$ \\
6 & $3.35 \pm 0.38$ & - & - \\
& $2.64 \pm 0.37$ & - & - \\
7 & $2.46 \pm 0.38$ & - & - \\
& $2.41 \pm 0.43$ & - & - \\
8 & $2.24 \pm 0.40$ & - & $44.25 \pm 2.82$ \\
& $1.81 \pm 0.39$ & $1.27 \pm 0.16$ & - \\
9 & $1.78 \pm 0.42$ & $1.14 \pm 0.14$ & - \\
& $1.53 \pm 0.32$ & - & $46.80 \pm 2.62$ \\
Z & $1.36 \pm 0.28$ & - & $38.73 \pm 5.26$ \\
\hline
\end{tabular}

"Green jungle fowl (male) $\times$ Gifu native fowl (female) hybrid (female).

2) Standard deviation. 


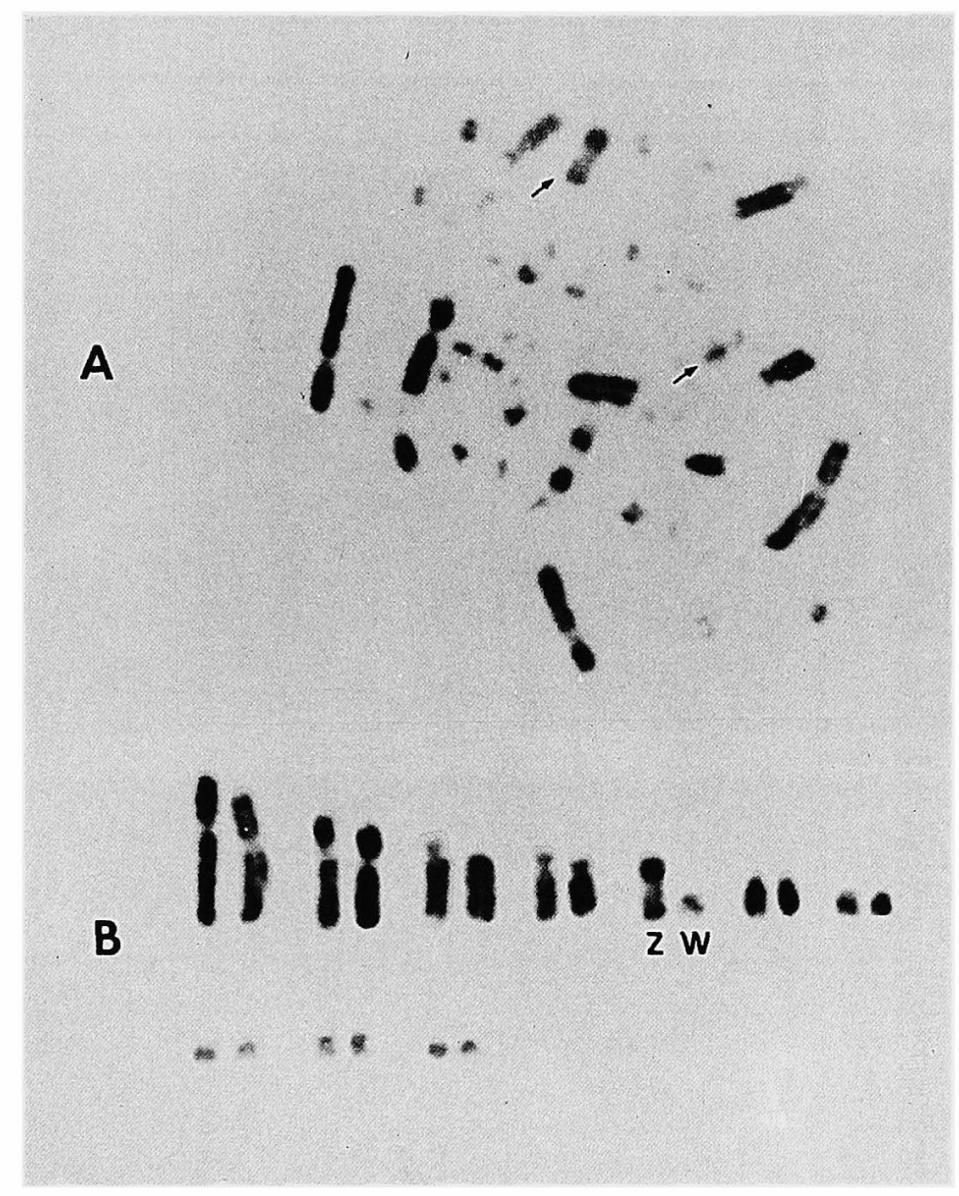

Fig. 1. Metaphase cell (A) and macrochromosomes (B) of Green jungle fowl-Gifu native fowl hybrid (female). Arrows show sex chromosomes (ZW).

のARの比較を表 2 に示した。なお，アオエリヤケイ の良好な中期像は少なく他の 2 種との統計的な検討はで きなかった． $F_{1}$ の Nos. 1，2，4については，相同染 色体間で AR の有意差が認められたが, No. 8 につい ては大型染色体群の中では形態が小さく相同対間の差は みられなかった。母親である吱阜地鶏と $\mathrm{F}_{1}$ の AR を 比較してみると, Nos. 1， 2 および 4 に扔いて， F 染色体は吱阜地鵎之有意差があるものとない屯のとに識 別することが可能であった，以上の結果をあとにこれら 3 種の大型染色体群を形態的に分類し，その結果を表 3 に示した。

G-分染法により $\mathrm{F}_{1}$ および岐阜地鶏の大型染色体群 （10対）にバンドが検出された（図 2).その他の微小染
色体群（29 対）では，染色体全体が濃染されバンドの 確認は困難であった。図 3 に $\mathrm{F}_{1}$ と岐阜地鶏の各染色体

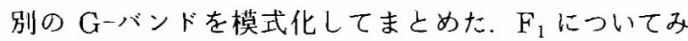
ると，各々の相同染色体閒では，バンドの幅，位置およ び数においてはほとんど違いは認められなかった。また， アオエリヤケイとの比較はできなかったが, 岐阜地鶏と 比較しても大きな差はみられなかった。

\section{考察}

野鷂とニワトリを交雑することにより得られる $F_{1}$ に 関しては，いくつかの報告がある。しかしながら，アオ エリヤケイとニワトリの閏で自然交雑により $\mathrm{F}_{1}$ を作出 した例はない. ニワトリの祖先の可能性として，4種の 
Table 2. Comparison of arm ratio among Gifu native fowl (Gi), $\mathrm{F}_{1}{ }^{\mathrm{l}}$ and Green jungle fowl (Gr).

\begin{tabular}{|c|c|c|c|}
\hline \multirow{2}{*}{$\begin{array}{l}\text { Chromosome } \\
\text { No. }\end{array}$} & Gi & $\mathrm{F}_{1}$ & Gr \\
\hline & $\left(\right.$ mean \pm S. D. $\left.{ }^{2)}\right)$ & (mean \pm S.D.) & \\
\hline \multirow[t]{2}{*}{1} & $1.60 \pm 0.12^{\mathrm{a}}$ & $1.52 \pm 0.16^{\mathrm{a}}$ & 1.71 \\
\hline & & $1.83 \pm 0.21^{\mathrm{b}}$ & \\
\hline \multirow[t]{2}{*}{2} & $1,80 \pm 0.17^{\circ}$ & $1.89 \pm 0.19^{\mathrm{a}}$ & 1.73 \\
\hline & & $1.64 \pm 0.46^{\mathrm{b}}$ & \\
\hline \multirow[t]{2}{*}{3} & - & $4.94 \pm 1.20$ & 5.11 \\
\hline & & - & \\
\hline \multirow[t]{2}{*}{4} & $3.41 \pm 0.20^{\mathrm{a}}$ & $3.32 \pm 1.90^{\mathrm{a}}$ & 3.64 \\
\hline & & $3.75 \pm 0.97^{b}$ & \\
\hline \multirow[t]{2}{*}{8} & $1.32 \pm 0.12^{\mathrm{a}}$ & $1.27 \pm 0.16^{\mathrm{b}}$ & 1.23 \\
\hline & & $1.14 \pm 0.14^{\circ}$ & \\
\hline $\mathrm{Z}$ & $1.16 \pm 0.08^{\mathrm{a}}$ & $1.14 \pm 0.12^{\mathrm{a}}$ & 1.04 \\
\hline W & $1.41 \pm 0.06^{\mathrm{a}}$ & $1.4510 .37^{\mathrm{a}}$ & - \\
\hline
\end{tabular}

${ }^{1)} \mathrm{Gr}$ (male) $\times \mathrm{Gi}$ (female) hybrid (female).

2) Standard deviation.

$a, b$ : Those means with the same superscript are not significantly different at $5 \%$ level.

Table 3. Type of macrochromosomes of Gifu native fowl (Gi), $F_{1}$ and Green jungle fowl (Gr).

\begin{tabular}{llll}
\hline Chromosome No. & $\mathrm{Gi}$ & $\mathrm{F}_{1}{ }^{11}$ & $\mathrm{Gr}$ \\
\hline 1,2 & $\mathrm{SM}^{21}$ & $\mathrm{SM}$ & $\mathrm{SM}$ \\
3 & $\mathrm{AC}^{31}$ & $\mathrm{AC}$ and $\mathrm{ST}^{41}$ & $\mathrm{ST}$ \\
4 & $\mathrm{ST}$ & $\mathrm{ST}$ & $\mathrm{ST}$ \\
$5,6,7,9$ & $\mathrm{AC}$ & $\mathrm{AC}$ & $\mathrm{AC}$ \\
$8, Z, \mathrm{~W}$ & $\mathrm{M}^{51}$ & $\mathrm{M}$ & $\mathrm{M}$ \\
\hline
\end{tabular}

" $\mathrm{Gr}$ (male) $\times \mathrm{Gi}$ (female) hybrid (female), "2 Submetacentric, " ${ }^{3)}$ Acrocentric,

4) Subtelocentric, ${ }^{5)}$ Metacentric.

野鹞を考えた場合、ニワトリとの閌で $\mathrm{F}_{1}$ ができるとい うここは重要なこ上であり，これまで目由に交尾を行な うのが望好られているのは，セキショタヤケイだけで， 他の3 種については，確誌されていなかった，

$\mathrm{F}_{1}$ の中期細胞を顕微镜下で観察してみると，No. 3 は次端部動原体型（Subtelocentric）㧍上び Acrocentricからなり相同対問で明らかに巽なった形態を示し， その由来の问定は谷易であった，その他の常染色体につ いては，形態的には相同対閏で同様に分類されたが， ARに上り Nos. 1，2 拉よび4染色体が由来が推定す ることができた，しかしながら，No.8染色体は，相 闰対間で大きさ朽よび AR がほとんど同じであり由来 を確諗することは困難であった。また，Nos，5，6，7 “扰よび 9 染色体は，AR を孝持たない Acrocentric で
あり，その形態加らの推定はできなかった。性染色体に ついては，交䧳に供武したアオェリヤケイが雄（ZZ）

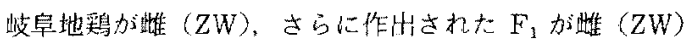
であったことから， $F_{1} の Z$ 染色体はアォエリヤヶイ由 来，W 染色体は岐阜地鷄由来であることは明白である. しかし， $F_{1}$ が雄である場合は，性染色体の由来につい てはさらに詳細な分析が必要であると思われる。

Gーバンドは，染色体の大きさが小さくなるに従い確 認古困難になる傾向があった， $F_{1}$ の相同染色体間にお けるバンドは，ほぼ同椂に出現し著しい差は認められず， また $F_{1}$ と皮阜地筃を比较してもバンドに関しては大き な相違は観察されず， $F_{1}$ の染色体の由来を $\mathrm{G}-$ バンド から追求することはできなかった。このことは今回 G分染去を行なうことができなかったアオエリヤケイにつ 

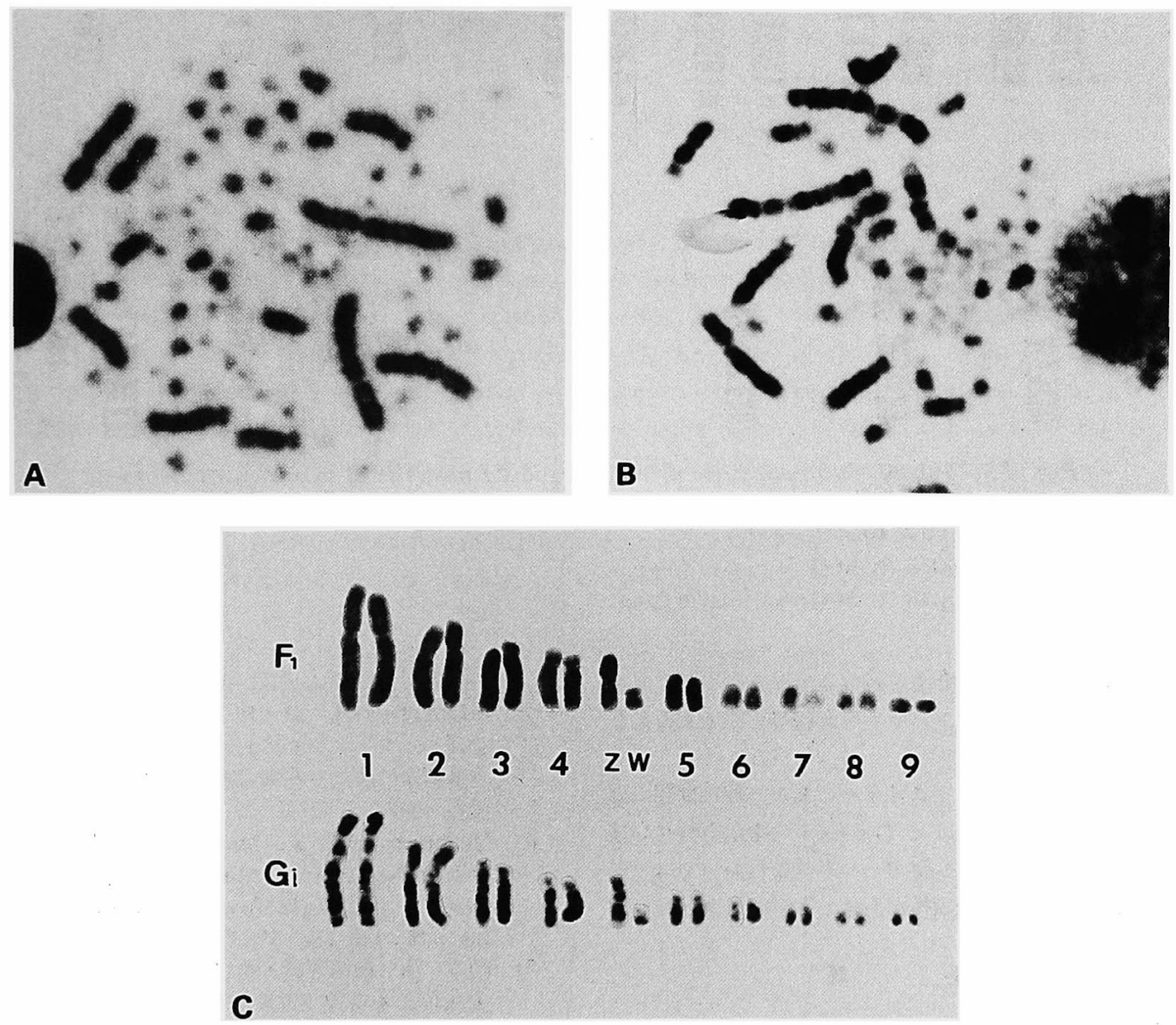

Fig. 2. G-banding patterns of Green jungle fowl-Gifu native fowl hybrid (female) and Gifu native fowl (female).

A : Hybrid. B: Gifu native fowl. C: Comparison of G-banding patterns of macrochromosomes. ( $F_{1}$ : hybrid, Gi: Gifu native fowl). 
岡本・中山・前田・橋口

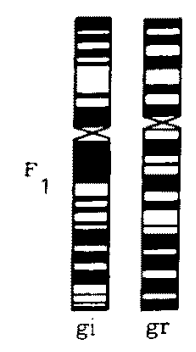

1

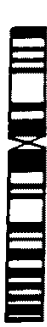

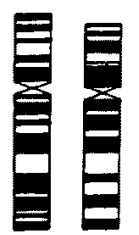

2

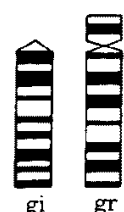

3

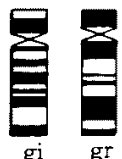

4
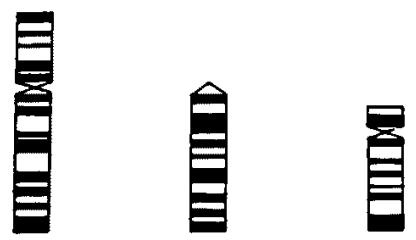

Fig. 3. Schematic illustration of the G-banding patterns of macrochromosomes.

$F_{1}$ : Green jungle fowl-Gifu native fowl hybrid (female).

Gi: Gifu native fowl (female).

gi : originated from Gifu native fowl.

gr : originated from Green jungle fowl.

いても，G-バンド分染法を行なえば扔をらくニワトリ とほとんど同様のバンドパターンが観察可能であること を示唆している。

以上のことから，アオエリヤケイおよび岐阜地鵎の染 色体は，その $\mathrm{F}_{1}$ について G-バンド分染法を行ない検 討してみると大型染色体群のバンドの型においては，両 者の間に非常に高い㥵同性があることが確認された。

\section{文献}

1) Denver Report 1960, A proposed standard system of nomenclature of human mitotic chromosomes. Lancet, i : 1063-1065. 1960.

2) Deraniyagala, P.E.P., Hybridization in the jungle fowl of Ceylon. Spoila Zeylanica, $1: 59-61.1953$.

3) Kimball, E., Personal communication, Landauer, W. Monograph 1. 183. Storrs Arg. Exp. Sta. Univ. Conn. Storrs. 1967.

4) London Report, The London Conference of the normal human karyotype. Cyto- genetics, $2: 264-268.1963$.

5）西田隆雄・野澤 謙・林 良博・橋口 勉・近藤 恭司，インドネシアにおける野鶏の生態学的およ び形態学的研究，在来家畜研究会報告, 10 ：155167. 1983.

6) OKamoto, S., Y. Maeda and T. HashiGUCHI, Analysis of the karyotypes of four species of jungle fowl. Jpn. J. Zootech. Sci., 59 : 146-151. 1988.

7）岡本 新・前田芳賽・憍口 勉, G-および C-分 染法による二ワトリの核型分析，日畜会報，60： 928-932. 1989.

8) OWEN, J.J.T., Karyotype studies on gallus domesticus. Chromosoma (Berl.), 16:601608. 1965 .

9) Seabright, M.A., A rapid banding technique for human chromosomes. Lancet, ii : 971. 1971 .

10) Shoffner, R.N., A. Krishan, G.J. Haiden, R.K. BAMmI and J.S. OTIS, Avian chromosome methodology. Poultry Sci., $46: 333-344.1966$. 


\title{
Analysis of the Karyotype of the Green Jungle Fowl (Male)-Gifu Native Fowl (Female) Hybrid
}

\author{
Shin Okamoto, Motoo Nakayama, Yoshizane Maeda \\ and T'sutomu HASHIGUCHI \\ Faculty of Agriculture, Kagoshima University, \\ Kagoshima-shi 890
}

\begin{abstract}
The present study was conducted to clarify the karyotype of the Green jungle fowl-Gifu native fowl hybrid $\left(F_{1}\right)$. The results are summarized as follows.

It was observed that the metaphase cell of $F_{1}$ lymphocyte consisted of macrochromosomes and microchromosomes. On analysis of the arm ratio and the centromeric index of 9 pairs of macrochromosomes and sex chromosomes, it was found which parents Nos. 1, 2, 3 and 4 chromosomes came from. In sex chromosomes, the Green jungle fowl used in this study was male (ZZ) and the Gifu native fowl was female $(Z W)$, so it was clear that the $Z$ chromosome of $F_{1}$ came from the former and the $W$ from the latter. But it was impossible to decide the origin of the Nos. 5, 6, 7,8 and 9 . On the other hand, there was a high analogy in $G$-banding pattern between $F_{1}$ and the Gifu native fowl.
\end{abstract}

Anim. Sci. Technol. (Jpn.) 62 (8): 735-741, 1991

Key words: Green jungle fowl, Gifu native fowl, hybrid, karyotype, chromosome 